\section{Internal Bruising Alters Aroma Volatile Profiles in Tomato Fruit Tissues}

\author{
Celso L. Moretti ${ }^{1}$ \\ Horticultural Sciences Department, University of Florida, Gainesville, \\ FL 32611
}

Elizabeth A. Baldwin

U.S. Department of Agriculture, Citrus and Subtropical Products Laboratory, Winter Haven, FL 33883

\section{Steven A. Sargent and Donald J. Huber \\ Horticultural Sciences Department, University of Florida, Gainesville, FL 32611}

Additional index words. Impact, Lycopersicon esculentum, mechanical injury, locule, pericarp, placenta

\begin{abstract}
Tomato (Lycopersicon esculentum Mill.) fruit, cv. Solar Set, were harvested at the mature-green stage and treated with $50 \mu \mathrm{L} \cdot \mathrm{L}^{-1}$ ethylene at $20{ }^{\circ} \mathrm{C}$. Individual fruits at the breaker stage $(<10 \%$ red color) were dropped onto a solid surface to induce internal bruising. Dropped and undropped fruit were stored at $2{ }^{\circ} \mathrm{C}$ until red-ripe, at which time pericarp, placental, and locule tissues were excised. Tissues from dropped tomatoes were examined for evidence of internal bruising and all tissues were analyzed for selected volatile profiles via headspace analysis. Individual volatile profiles of the three tissues in bruised fruit were significantly different from those of corresponding tissues in undropped, control fruit, notably: trans-2-hexenal from pericarp tissue; 1-penten-3-one, cis-3-hexenal, 6-methyl-5-hepten-2-one, cis-3-hexenol and 2-isobutylthiazole from locule tissue; and 1penten-3-one and $\beta$-ionone from placental tissue. Alteration of volatile profiles was most pronounced in the locule tissue, which was more sensitive to internal bruising than the other tissues. Changes observed in the volatile profiles appear to be related to disruption of cellular structures.
\end{abstract}

The postharvest quality of fresh tomato fruit is determined by many attributes including appearance, firmness, flavor, and nutritional value (Kader et al., 1978). Flavor is perceived through a combination of odor, taste, and mouth feel, and can be defined as a balance among sugars, organic acids, volatile compounds, and free amino acids (Petró-Turza, 1987). More than 30 volatile components were identified from fresh tomato headspace by Buttery et al. (1989), of which nine were determined to play a major role in aroma. Mechanical injuries have been shown to be correlated with metabolic and quality changes in many commodities, such as tomato (Lycopersicon esculentum Mill.), sweetpotato (Ipomoea batatas), citrus (Citrus sinensis Osbeck), and melons (Cucumis melo spp.). Citric and malic acid increased transiently in tomato fruit during ripening after vibration

Received for publication 20Feb. 2001. Accepted for publication 30 Aug. 2001. Florida Agriculture Experiment Station Journal Series No. R-07949. We are grateful to Dr. Stephen Olson, NFREC-Quincy, for providing experimental material, and Ms. Holly Hisson and Ms. Abbie Fox for their help in the chemical analyses.

${ }^{1}$ To whom reprint requests should be addressed. Current address: National Vegetable Crops Research Center, Brasilia, CP218, 70.359-970, Brazil.

E-mail: celso@cnph.embrapa.br. bruising (Nakamura et al., 1977). Sweetpotatoes showed a $72 \%$ increase in the respiration rate after physical impact (Saltveit and Locy, 1982). Belknap et al. (1990) observed that mechanical injuries associated with superficial tissue disruption generally increased melanin content in potatoes (Solanum tuberosum L.). Mechanical stresses are also related to increases in 1-aminocyclopropane1-carboxylic acid (ACC) synthase and ACC oxidase in winter squash (Cucurbita maxima Duch.) (Hyodo et al., 1993).

Physical impacts of tomato fruit can cause internal bruising, a physiological disorder that results from an impairment of normal ripening (Halsey, 1955). This injury typically lacks any external blemish and, therefore, is only detectable upon consumption. Hatton and Reeder (1963) described tomato fruit with internal bruising as having a disorganized, collapsed, and cloudy locule tissue. Sargent et al. (1992) observed that tomato fruit at the breaker stage were more susceptible to internal bruising than fruit at the mature-green stage. MacLeod et al. (1976) observed that ethylene and $\mathrm{CO}_{2}$ evolution increased with the number of impacts. Moretti et al. (1998) observed that impact bruising increased ethylene and carbon dioxide evolution, and altered chemical composition and physical properties of impacted pericarp and locule tissues, resulting in fruits with lower quality attributes. In another set of experiments, Moretti et al. (1997) conducted sensory analysis tests (difference-from-control tests) to study consumer acceptability of tomato fruit with internal bruising. They verified that panelists were able to differentiate flavor in homogenates prepared with bruised and unbruised fruits at red-ripe stage. Some of the panelists described the internally bruised fruits as "watery" or " bland" in flavor. These results suggested that alterations in tomato flavor compounds, in addition to sugars and acids, could be associated with mechanical injuries such as internal bruising.

Although there have been several reports focusing on internal bruising and its consequences on fruit physiology and quality, there is still a lack of information regarding changes in aroma volatile profiles in tomatoes with this disorder. The purpose of this investigation was to study the effects of internal bruising on aroma volatile profiles in pericarp, locule, and placental tissues of tomato fruit.

\section{Material and Methods}

Plant material. Mature-green tomatoes, cv. Solar Set, were hand harvested at the Univ. of Florida's North Florida Research and Education Center-Quincy in Oct. 1996, for the first experiment, and at a commercial field in the Bradenton, Fla. area in Dec. 1996, for the second experiment. At harvest, fruits were placed into polystyrene cell-pack trays (Niles Packaging, Niles, Mich.) to avoid mechanical damage and transported to the postharvest laboratory in Gainesville the same day.

Ethylene treatment and impact bruising. Fruits were sorted for blemishes and graded for size (medium fruits $=63$ to $72 \mathrm{~mm}$ ) and weight $(140 \pm 10 \mathrm{~g})$ and exposed to $50 \mathrm{~mL} \cdot \mathrm{L}^{-1}$ of humidified ethylene in an enclosed chamber using a flow-through system (flow rate $=$ $\left.50 \mathrm{~mL} \cdot \mathrm{s}^{-1}\right)$ at $20{ }^{\circ} \mathrm{C}$. At breaker stage $(<10 \%$ red color; U.S. Dept. of Agriculture, 1976), tomatoes were suspended by vacuum to avoid fruit rotation during the $40-\mathrm{cm}$ drop onto a solid, metallic smooth surface. Each fruit was dropped twice, one at each of two equidistant points on the fruit equator avoiding radial pericarp walls. Following the impacts, fruits were stored along with undropped fruits at 20 ${ }^{\circ} \mathrm{C}$ and $85 \%$ to $90 \%$ relative humidity until they reached the red-ripe stage. The red-ripe stage was defined as the point at which fully red fruit had a deformation of 3 to $4 \mathrm{~mm}$. Firmness was measured using the Cornell device (Hamson, 1952) as modified by Gull et al. (1980), in which a static force of $9.8 \mathrm{~N}$ was applied to the equator with a convex probe (11 $\mathrm{mm}$ in diameter) and the deformation determined after $5 \mathrm{~s}$.

Tissue analysis. At the red-ripe stage of ripening, pericarp, locule and placental tissues (Hobson and Davies, 1971) were excised separately and analyzed for aroma volatile profiles. Pericarp tissue was considered as the tissue originating from the ovary wall that surrounds and encloses the seeds. Radial pericarp walls were not analyzed. Locule tissue was considered as the jelly-like parenchyma- 
tous tissue, including seeds, originating from the placenta. Placental tissue was that having seeds attached over its surface and showing a distinct border with the inner wall of the pericarp or columnella. The key flavor components quantified in this study were hexanal, trans-2-hexenal, cis-3-hexenal, cis-3hexenol, 2-isobutylthiazole, 6-methyl-5hepten-2-one, 1-penten-3-one, and $\beta$-ionone (Buttery et al., 1971, 1987, 1988, 1993a, 1993b; Petró-Turza, 1987).

Tissue preparation. Tissues were homogenized separately in a blender (Hamilton Beach/Proctor Silex, Washington, N.C.) for $30 \mathrm{~s}$ and held for $180 \mathrm{~s}$ at room temperature, according to a procedure described by Buttery et al. (1987), with the following modifications. Ten $\mathrm{mL}$ of saturated $\mathrm{CaCl}_{2}$ were added to $25 \mathrm{~mL}$ of homogenate in order to minimize any changes due to enzyme activity, and blended again for $10 \mathrm{~s}$ (Baldwin et al., 1992). The resulting homogenate was transferred to plastic bags and frozen in liquid $\mathrm{N}_{2}$. Bags were stored at $-80{ }^{\circ} \mathrm{C}$ until analysis.

Volatile compounds analysis. Volatile analysis was based on a methodology developed for citrus fruit and juice products by Nisperos-Carriedo and Shaw (1990) and adapted for tomatoes by Baldwin et al. (1991). Two $\mathrm{mL}$ of each sample were transferred to 6-mL glass vials that were hermetically sealed and frozen at $-20^{\circ} \mathrm{C}$. Volatile flavor components were determined using a gas chromatograph (model 8500; Perkin Elmer, Crestek Corp, Bellafonte, Pa.), equipped with a headspace sampler (model HS-6; Perkin Elmer) with a $0.53 \times 30$-mm Stabilwax column and a flame ionization detector. The components were identified by comparison of retention times with those of standards and by enrichment of tomato homogenates with authentic samples. Concentrations were calculated using regression equations, determined by injecting five concentrations of each standard to obtain a peak height calibration curve (Baldwin et al., 1991).

Statistical analysis. Experiments were carried out using a completely randomized design with two treatments (bruised and unbruised fruit) and four replications $(n=10$ fruit). Data were subjected to analysis of variance using the general linear model (GLM) procedure of the Statistical Analysis System package (SAS Institute, Cary, N.C.). Differences between treatments were determined by $\mathrm{F}$ test. All comparisons were made at $P=0.05$. Since the two experiments had similar trends, only the results of the first experiment are shown.

\section{Results and Discussion}

Aroma volatile profiles in unbruised and bruised tomatoes varied according to tissue type. Hexanal (Fig. 1a), cis-3-hexenal (Fig. 1b), and trans-2-hexenal (Fig. 1c) were present in the highest concentrations, whereas $\beta$-ionone (Fig. 2c) and 2-isobutylthiazole (Fig. 3b) had the lowest concentration in the three tissues studied. Buttery et al. (1988) also observed that hexanal and cis-3-hexenal were among the
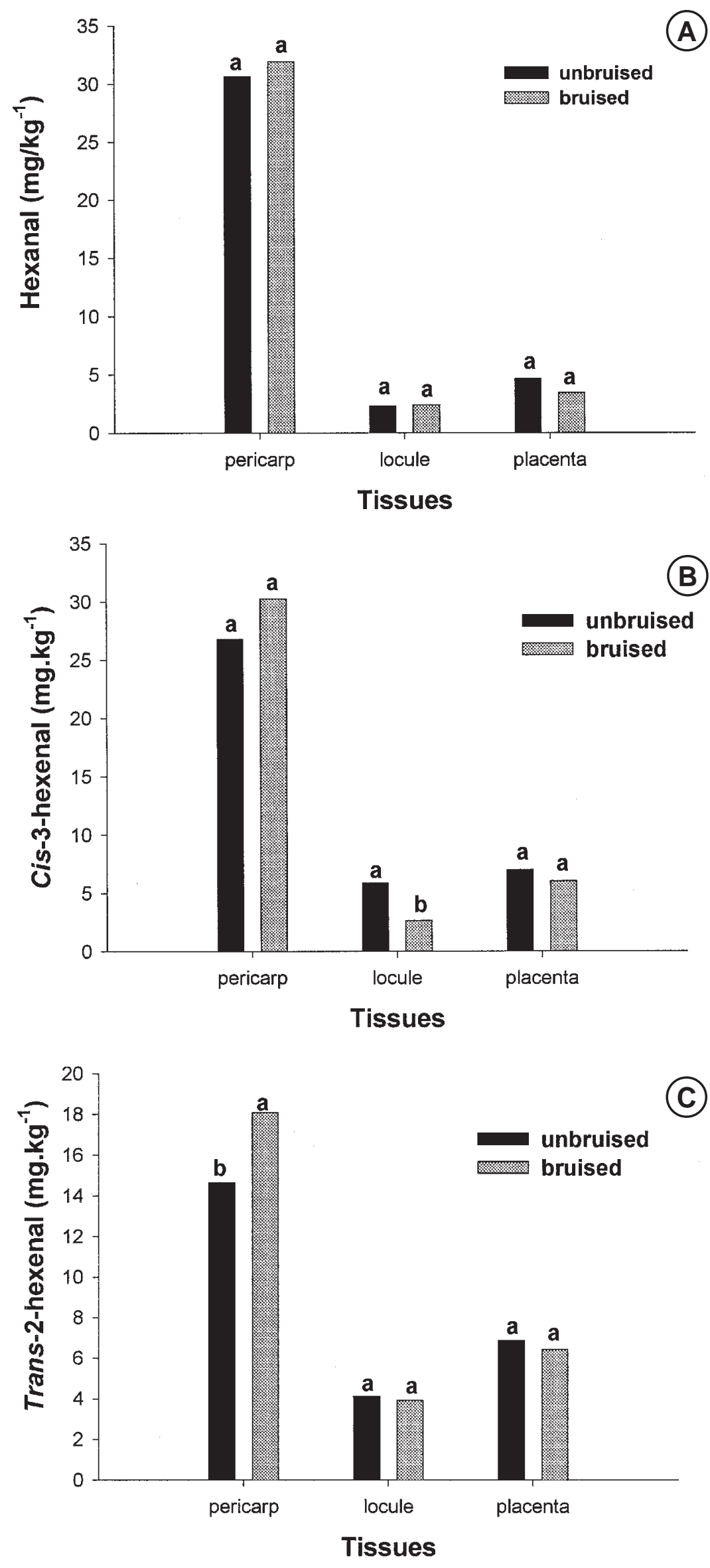

Fig. 1. Aldehyde volatile profiles of pericarp, locule, and placental tissue of bruised and unbruised tomato fruit. For each tissue, different letters represent significant differences between bruised and unbruised fruit $(P=0.05)$. (A) hexanal; (B) cis-3-hexenal; (C) trans-2-hexenal. 
compounds showing high concentrations in the pulp and fluid (locule tissue without seeds) of tomato fruit.

Physical impacts induced significant changes in volatile profiles in the pericarp, locule and placental tissues as compared to unbruised tissues. Bruised pericarp tissue showed significant alterations in trans-2-hexenal concentration, being $19 \%$ higher in bruised tissue than in unbruised tissue (Fig. 1c). Unbruised locule tissue had $122 \%, 34 \%, 33 \%, 44 \%$, and $57 \%$ more cis-3-hexenal (Fig. 1b), 6-methyl-5hepten-2-one (Fig. 2a), 1-penten-3-one (Fig. 2b), cis-3-hexenol (Fig. 3a), and 2-isobutylthiazole (Fig. 3b) than bruised locule tissue, respectively. Placental tissue was also significantly affected by physical impact, where bruised placental tissue had $35 \%$ and $67 \%$ more 1-penten-3-one (Fig. 2b) and $\beta$-ionone (Fig. 2c) than unbruised tissue.

Fresh tomato flavor is characterized primarily by volatile compounds that are derived from the metabolism of amino and fatty acids and from the breakdown of carotenoids (Buttery et al., 1971, 1988). Disruption of cellular structures and alteration in ionic strength brought about by physical impact (Moretti et al., 1998) may have caused enzymes to prematurely react with their specific substrates, enhancing the formation of enzymic oxidation products and promoting the degradation pathway of tomato acyl lipids in pericarp and placental tissues. Isomerases, lipoxygenases and peroxidases are enzymes involved in the metabolism of tomato lipids (Petró-Turza, 1987). Besides increasing carbon dioxide and ethylene evolution (MacLeod et al. 1976; Moretti et al., 1998), physical impact may have increased the activity of isomerase, the enzyme involved in the isomerization of $\mathrm{cis}$-3hexenal into trans-2-hexenal in the presence of $\mathrm{H}^{+}$ions, although this reaction can also occur nonenzymatically (Buttery et al., 1988). Trans-2-hexenal is a compound that is believed to be more stable than cis-3-hexenal, although it has a lower odor threshold (PetróTurza, 1987).

Disruption in the fatty acid degradation pathway is also believed to be involved in the alterations observed in cis-3-hexenal, cis-3hexenol, and 1-penten-3-one. Physical impact may have altered the enzymatic oxidation of linolenic acid, specifically the activity of lipoxygenases and other peroxidases, leading to a significant decrease in cis-3-hexenal in locule tissue. Since $c i s-3$-hexenal is a precursor of cis-3-hexenol in the same pathway through the action of alcohol oxidoreductase (Petró-Turza, 1987), a decrease in the levels of cis-3-hexenal may have had a direct effect on the concentration of cis-3-hexenol.

In this study, the concentration of 1-penten3 -one decreased in bruised locule tissue and increased in placental tissue (Fig. 2b). Hofman (1962) observed that the oxidation of linoleic acid yields, among other substances, methylethyl ketones that have a close structural similarity with 1-penten-3-one. Buttery and Ling (1993) also reported this volatile to be lipid derived. Therefore, physical impact may have caused the oxidation of linoleic acid, increas-
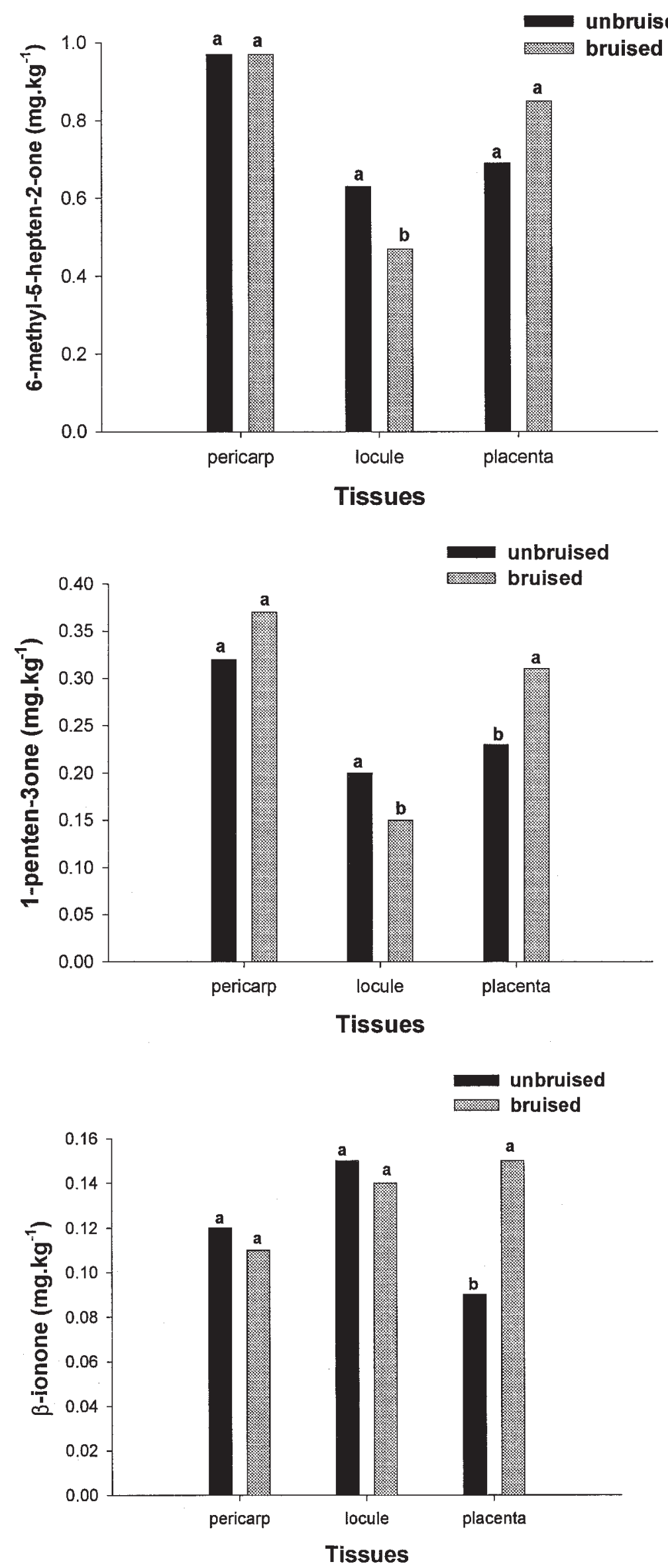

Fig. 2. Ketone volatile profiles of pericarp, locule, and placental tissue of bruised and unbruised tomato fruit. For each tissue, different letters represent significant differences between bruised and unbruised fruit $(P=0.05)$. (A) 6-methyl-5-hepten-2-one; (B) 1-penten-3-one; (C) $\beta$-ionone. 

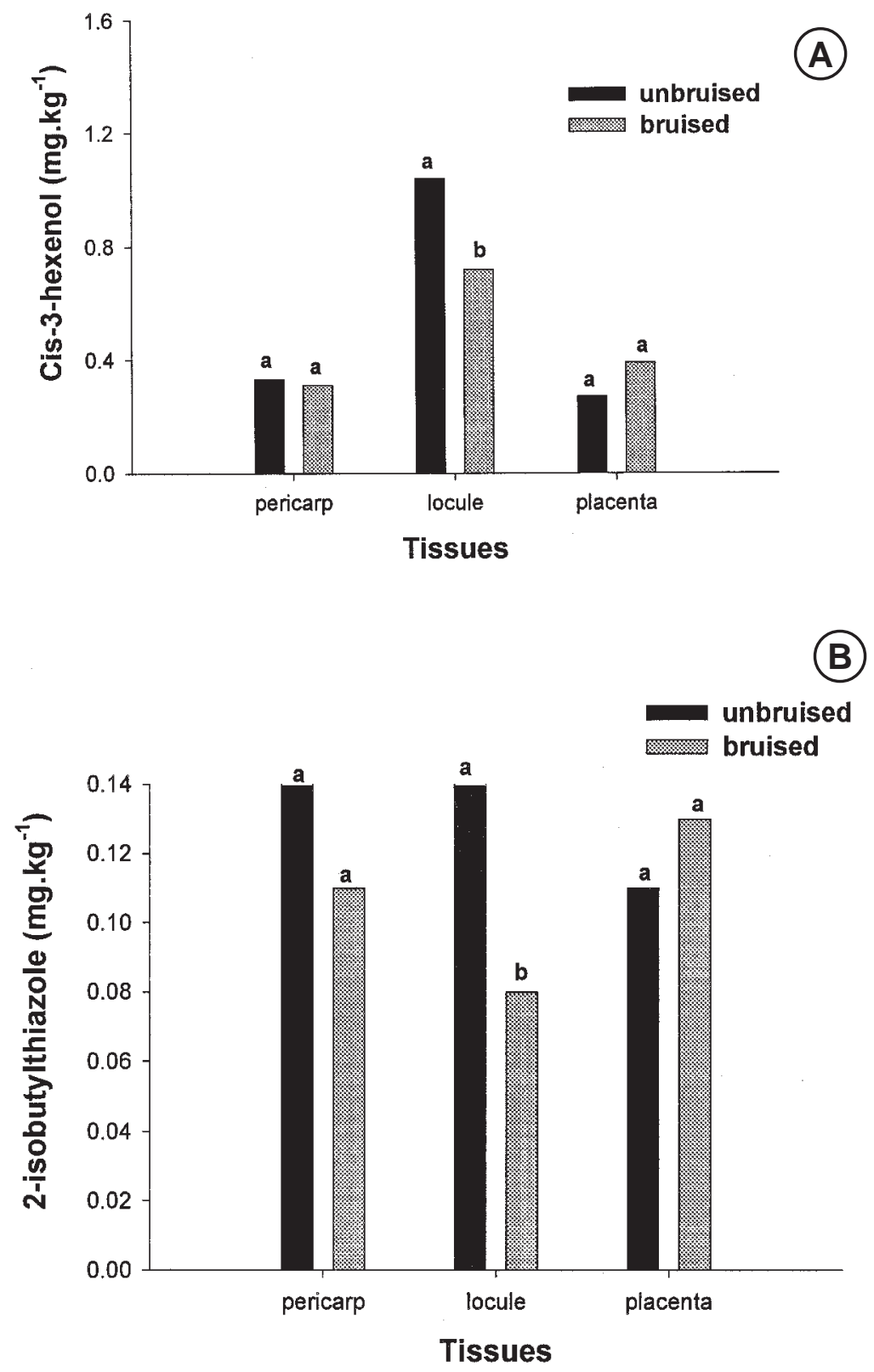

Fig. 3. Alcohol and sulfur-containing volatile profiles of pericarp, locule, and placental tissue of bruised and unbruised tomato fruit. For each tissue, different letters represent significant differences between bruised and unbruised fruit $(P=0.05)$. (A) cis-3-hexenol; (B) 2-isobutylthiazole.

ing the concentration of 1-penten-3-one placental tissues. The reduction of this volatile in locule tissue after a physical impact is not completely understood.

Buttery and Ling (1993b) reported that 6methyl-5-hepten-2-one and $\beta$-ionone are volatiles originating from open- and cyclicchain carotenoids, respectively. Moretti et al. (1998) reported that locule tissue showed a lower carotenoid concentration following physical impact. Changes in carotenoid concentration due to impact bruising may have contributed to the reduction of 6-methyl-5hepten-2-one levels in locule tissue and to the increase of $\beta$-ionone concentration in placental tissue (Fig. 2 a and c).

Impact bruising also significantly decreased 2-isobutylthiazole concentration in locule tis- sue (Fig. 3b). It is suggested that impact bruising may have altered biosynthetic pathways of amino acids, specifically isoleucine which is involved in 2-isobutylthiazole synthesis (Buttery and Ling, 1993a).

Buttery and Ling (1993a) reported that tissue disruption during sample preparation was the cause of increases in cis-3-hexenal, trans-2-hexenal and 1-penten-3-oneconcentrations and a slight increase in 6-methyl5-hepten-2-one. However, the opposite results obtained in the present study suggest that the physical impact and subsequent physiological and metabolic-associated alterations apparently contributed to a reduction in the concentration of these volatiles prior to tissue maceration and analysis (Moretti et al., 1998).
According to our data, locule tissue ripening was markedly affected by physical impact. This result is in line with the work of Halsey (1955), McColloch (1962), Sargent et al. (1992), and Moretti et al. (1998). Locule tissue components are more fluid and more readily perceived by taste receptors, and therefore a greater contribution to tomato flavor than other tissues (Stevens et al., 1977). Tightly bound pericarp cells may have a crucial role in the transmission of impact energy to the underlying locule tissue, resulting in maximum expression of internal bruising symptoms.

Changes in aroma volatile profiles of bruised tissues observed in the present work explain, in part, the reduction in flavor quality of bruised tissue noted by taste panelists (Moretti et al., 1997). The bland flavor that some panelists reported could have been due to disruption of biosynthetic pathways for compounds such as cis-3-hexenal (green aroma), cis-3-hexenol (green flavor), and 6methyl-5-hepten-2-one (fruity aroma) (PetróTurza, 1987).

Alterations in aroma volatile profiles following physical impact are probably associated with disruption in the metabolism of fatty acids (linoleic and linolenic acids), amino acids (isoleucine), and pigments (cyclic and open-chain carotenoids) during fruit ripening. Glucu et al. (1989) observed that following a respiratory upsurge, a sudden breakdown of total lipids occurs concomitantly with maximal ethylene production. The main changes that occurred in key aroma volatiles for the three tomato tissues following the physical impact are summarized (Fig. 4).

Future investigation should focus on the specific activity of enzymes such as peroxidases, lipoxygenases, reductases, and other hydrolases in bruised and unbruised tomato tissue. The effect of impact bruising on these enzymes could explain flavor alterations and other physiological changes that occur in affected tissues.

\section{Literature Cited}

Baldwin, E.A., M.O. Nisperos-Carriedo, and M.G. Moshonas. 1991. Quantitative analysis of flavor and other volatiles and for other constituents of two tomato cultivars during ripening. J . Amer. Soc. Hort. Sci. 116:265-269.

Baldwin, E.A., M.O. Nisperos-Carriedo, and J.W. Scott. 1992. Levels of flavor volatiles in a normal cultivar, ripening inhibitor, and their hybrid. Proc. Fla. State Hort. Soc. 104:86-89.

Belknap, W.R., T.M. Rickey, and R.R. Rockhold. 1990. Blackspot bruise dependent changes in enzyme activity and gene expression in Lemhi Russet potato. Amer. Potato J. 67:253-265.

Buttery, R.G. 1993. Quantitative and sensory aspects of flavor of tomato and other vegetables and fruits, p. 259-286. In: T.E. Acree and R. Teranishi (eds.). Flavor science: Sensible principles and techniques. Amer. Chem. Soc., Washington, D.C.

Buttery, R.G and L.C. Ling. 1993a. Enzymatic production of volatiles in tomatoes. In: Schereir and P. Winterhalter (eds.). Flavor precursors. Allure Publishing Co., Wheaton, Ill.

Buttery, R.G and L.C. Ling. 1993b. Volatile compounds of tomato fruit and plant parts: Relation- 

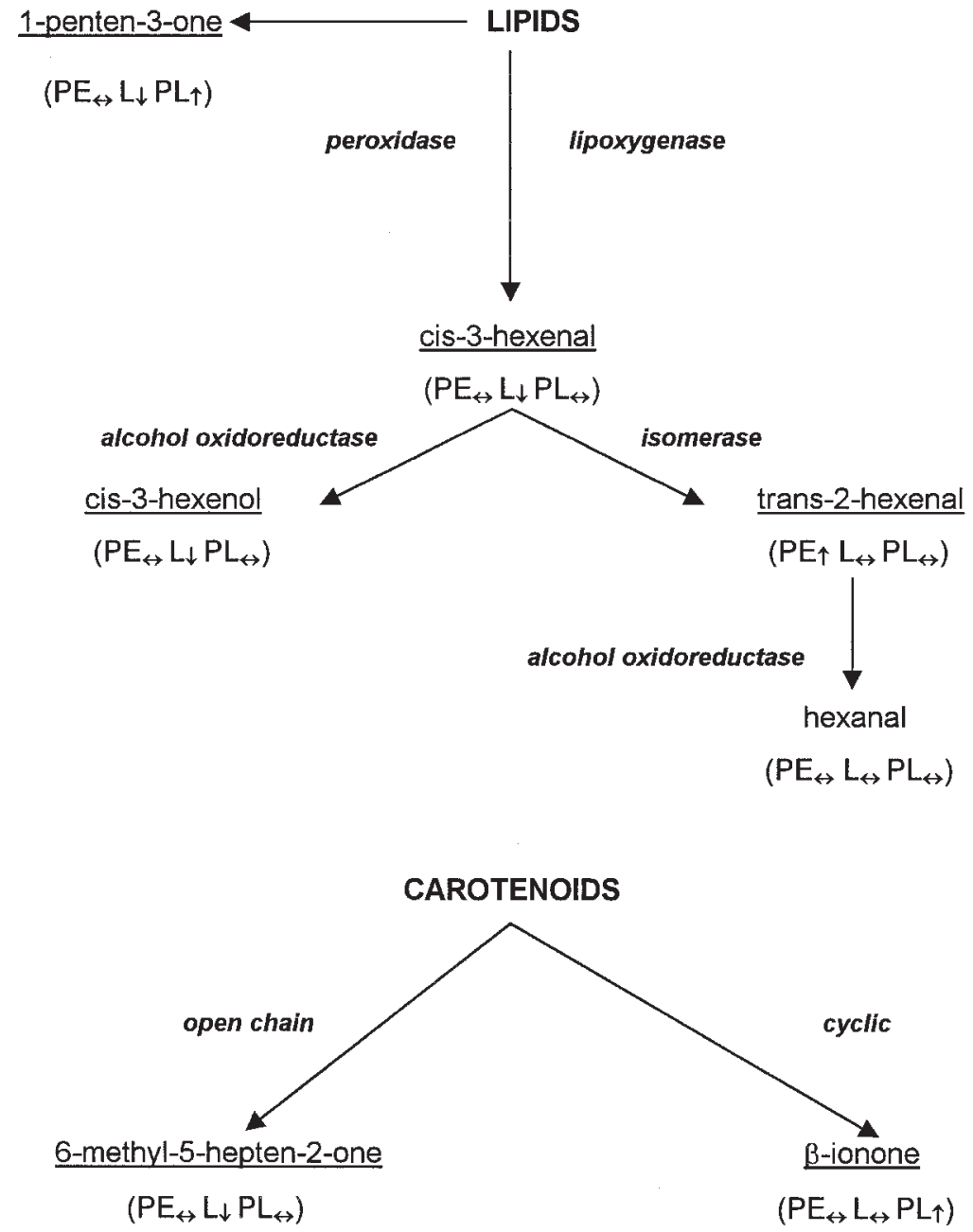

ISOLEUCINE

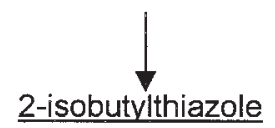

$\left(P E_{\leftrightarrow} L_{\downarrow} P L_{\leftrightarrow}\right)$

Fig. 4. Summary of degradation pathways of volatiles from pericarp, locule, and placental tissues. Each tissue was excised from dropped tomatoes, and specific volatiles were ranked according to relative change from the respective tissue taken from undropped tomatoes. Changes for each volatile are illustrated within parentheses, where pericarp $=\mathrm{PE}$, locule $=\mathrm{L}$, placenta $=$ PL. Subscripted symbols represent: $\leftrightarrow=$ no change; $\uparrow=$ increase; $\downarrow=$ decrease. (Adapted from Petró-Turza, 1987).

ship and biogenesis. Amer. Chem. Soc., Symp. Ser., Washington, D.C. 525:23-34.

Buttery, R.G., R.M. Seifert, D.G. Guadagni and L.C. Ling. 1971. Characterization of additional volatile components of tomato. J. Agr. Food Chem. 19:524-529.

Buttery, R.G., R. Teranishi, and L.C. Ling. 1987. Fresh tomato aroma volatiles: A quantitative study. J. Agr. Food Chem. 35:540-544.

Buttery, R.G., R. Teranishi, R.A. Flath, and L.C. Ling. 1989. Fresh tomato volatiles: Composition and sensory studies, p. 213-222. In: R.
Teranishi, R.G. Buttery, and F. Shahidi (eds.). Flavor chemistry: Trends and development. Amer. Chem. Soc., Washington, D.C.

Buttery, R.G., R. Teranishi, L.C. Ling, R.A. Flath, and D.J. Stern. 1988. Quantitative studies on origins of fresh tomato aroma volatiles. J. Agr. Food Chem. 36:1247-1250.

Guclu, J, A. Paulin, and P. Soudain. 1989. Changes in polar lipids during ripening and senescence of cherry tomato (Lycopersicon esculentum): Relation to climacteric and ethylene increases. Physiologia Plant. 77:413-419.
Gull, D., D. Cartagena, and E.C. French. 1980. Análisis de calidad de tomate para lograr um mejor producto. IBTA, PRODES, UFLA, Cochabamba, Bolivia. $20 \mathrm{p}$

Halsey, L.H. 1955. Preliminary studies of bruising of "turning" and "pink" tomatoes caused by handling practices. Proc. Fla. State Hort. Soc. 68:240-243.

Hamson, A.R. 1952. Measuring firmness of tomatoes in a breeding program. Proc. Amer. Soc. Hort. Sci. 60:425-433.

Hatton, T.T. and W.F. Reeder. 1963. Effect of field and packinghouse handling on bruising of Florida tomatoes. Proc. Fla. State Hort. Soc. 76:301-304.

Hobson, G.E. and J.N. Davies. 1971. The tomato. In: A.C. Hulme (ed.). The biochemistry of fruits and their products. Academic Press. New York. $2: 437-482$.

Hofman, G. 1962. 1-Octen-3-ol and its relation to other oxidative cleavage products from esters of linoleic acid. J. Amer. Oil Chem. 39:439-444.

Hyodo, H., C. Hashimoto, S. Morozumi, M. Ukai, and C. Yamada. 1993. Induction of ethylene production and lignin formation in wounded mesocarp tissue of Cucurbita maxima L. Acta Hort. 343:264-269.

Kader, A. A., L.L. Morris, M.A. Stevens, and M.A. Holton. 1978. Composition and flavor quality of fresh market tomatoes as influenced by some postharvest handling procedures. J. Amer. Soc. Hort. Sci. 103:6-13.

MacLeod, R. F., A.A. Kader, and L.L. Morris. 1976. Stimulation of ethylene and $\mathrm{CO}_{2}$ production of mature-green tomatoes by impact bruising. HortScience 11:604-606.

McColloch, L.P. 1962. Bruising injury of tomatoes. U.S. Dept. Agr. Mktg. Res. Rpt. No. 513.

Moretti, C.L., S.A. Sargent, C.A. Sims, and R. Puschmann. 1997. Flavor alteration in tomato fruit due to internal bruising. Proc. Fla. State Hort. Soc. 110:195-197.

Moretti, C.L., S.A. Sargent, D.J. Huber, A.G. Calbo, and R. Puschmann. 1998. Chemical composition and physical properties of pericarp, locule and placental tissues of tomatoes with internal bruising. J. Amer. Soc. Hort. Sci. 123:656660.

Nakamura, R., T. Ito, and A. Inaba. 1977. Effect of vibration on the respiration of fruits. 2. Effects of vibration on the respiration rate and quality of tomato fruit during ripening after vibration. J. Japan Soc. Hort. Sci. 46:349-360.

Nisperos-Carriedo, M.O. and P. Shaw. 1990. Comparison of volatile flavor components in fresh and processed orange juice. J. Food Agr. Chem. 38:1048-1052.

Petró-Turza, M. 1987. Flavor of tomato and tomato products. Food Rev. Intl. 2:309-351.

Saltveit, M.E. Jr. and R.D. Locy. 1982. Cultivar differences in ethylene production by wounded sweet potato roots. J. Amer. Soc. Hort. Sci. 107:1114-1117.

Sargent. S.A., J.K. Brecht, and J.J. Zoellner. 1992. Sensitivity of tomatoes at mature green and breaker ripeness stages to internal bruising. J. Amer. Soc. Hort. Sci. 117:119-123.

SAS Institute, Inc. 1985. The SAS program for personal computer. SAS Inst., Cary, N.C.

Stevens, M.A., A.A. Kader, and M. Albright-Holton. 1977. Intercultivar variation in composition of locular and pericarp portions of fresh market tomatoes. J. Amer. Soc. Hort. Sci. 102:689-692.

U.S. Dept. of Agriculture. 1976. United States standard for grades of fresh market tomatoes. Agr. Mktg. Serv., Washington D.C. 